\title{
Independence and Nationhood
}

Scotland 1306 - 1469 

Independence

and Nationhood

Scotland 1306 - 1469

Alexander Grant 
- Alexander Grant 1984

First published 1984 in The New History of Scotland series by Edward Amold (Publishers) Ltd and reprinted in 1991, 1992 , 1996, 2001

Edinburgh University Press

22 George Square, Edinburgh

Transferred to digital print in 2007

Printed and bound by CPI Antony Rowe, Eastbourne

British Library Cataloguing in Publication Data

Grant, Alexander

Independence and nationhood: Scotland 1306-1469-

(The new history of Scotland; 3)

1. Scotland - History - 1057-1603

I. Title II. Series

941.103 DA783

ISBN-10 0748602739

ISBN-13978074860273 5 